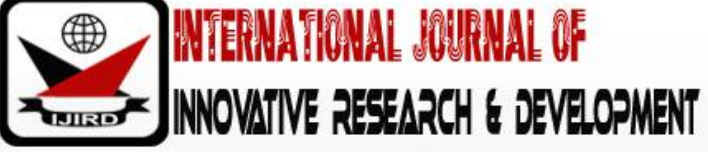

ISSN 2278-0211 (Online)

\section{Assessment of Hydrocarbons in Soil along Crude Oil Pipeline Route in Rivers State, Nigeria}

Iyebor, Ekene Wisdom
Ph.D. Research Scholar, Institute of Geosciences and Space Technology,
Rivers State University, Port Harcourt, Nigeria
Abam, Tamunoene Kingdom S.
Professor, Institute of Geosciences and Space Technology,
Rivers State University, Nigeria
Ngah Sabastian Amauche
Professor, Institute of Geosciences and Space Technology,
Rivers State University, Nigeria
UbongIni Ubong
Associate Professor in the Institute of Pollution Studies,
Rivers State University, Nigeria
Ndukwu Obed
Ph.D. Research Scholar,Instituteof Geosciences and Space Technology,
Rivers State University, Nigeria

\begin{abstract}
:
The spillage of crude oil from the network of pipelines in the Niger Delta has been a source of concern. As a result, it became necessary to assess the extent of soil contamination along a pipeline route in Rivers State. The concentrations of TPH, PAHs and BTEX in soil along crude oil pipeline route were investigated. The pipelines are located in Idu communities, near Port Harcourt, Rivers State, Nigeria. Sampling of soils was done at two depths $(0-15 \mathrm{~cm}$ and $15-30$ $\mathrm{cm}$ ) quarterly (January, April, July and October) at ten (10) stations and one control point, established at $1.5 \mathrm{~km}$ from the sampling stations. TPH, PAHs and BTEX in soils were analyzed using the GC-FID and Headspace respectively. The results obtained revealed that the soil was strongly contaminated with TPH and PAHs while BTEX was not detected. The concentrations $(\mathrm{mg} / \mathrm{kg})$ of $\mathrm{TPH}(371.83,368.34,353.00,326.38$ and320.84, 349.75, 303.39, 327.93) and PAHs (18.09, $25.94,17.38,17.96$ and $12.10,19.35,12.86,16.61)$ obtained in surface and subsurface soils respectively were not significantly different ( $p>0.05)$ across the four quarters of the year. However, there was significant difference $(p<0.05)$ across the sampling stations. The degree of hydrocarbons contamination of soil was SS $7>$ SS $8>$ SS $10>$ SS $6>$ SS $5>$ SS $4>S S 9>S S 1>S S 3>$ SS 2. The TPH and PAH concentrations obtained in soil exceeded their respective target values of the DPR in oil spilled soil nevertheless, below their respective intervention limits.
\end{abstract}

Keywords: Crude oil pipelines, pollution, soil, groundwater, TPH, PAHs, BTEX

\section{Introduction}

There is no contradiction that crude oil is in high demand around the world. The economies of numerous nations including Kuwait, UAE, Libya, Ecuador, Saudi Arabia, Qatar, Nigeria, etc, rely on oil income to fuel their economic development (Bhattacharyya and Adon, 2010). The current world petrol consumption is estimated at 99.5 million barrels per day (SRWE, 2018). In the United States of America for example, approximately 20 million barrels of oil were consumed daily in 2003 (Parry and Darmstadter, 2003). In 2018, the country's daily petrol consumption was estimated at 20.5 million barrels indicating a 5 million barrel increase in consumption within the period (USEIA, 2019). In Australia, daily consumption of petrol is estimated at 1.1 million barrels (CEIC, 2019). According to Europe's Energy Portal (2018), China, Japan and India consumed daily; 13 million, 4 million and 5 million barrels of petrol respectively. In Africa, Nigeria and Algeria are among the highest consumers of petrol with daily consumption of 500 and 420 thousand barrels respectively. These records indicate that crude oil is a necessary part of the modern world. Speight (Speight, 1999), observed that the world's economy is highly dependent on crude oil and its products for energy production and widespread use has led to enormous releases of contaminants and pollutants into the environment. Pipelines are critical oil and gas infrastructure in the sense that they are used to convey unrefined petroleum and oil based commodities from creation stages and processing plants to capacity terminals (depots).Globally, oil and natural gas pipelines are the two general sorts of energy pipelines. Inside the oil pipeline network, there are both unrefined lines and refined products lines (Arosanyin, 2005). Nnah and Owei (2005), noted that petroleum pipelines are fundamental methods of transportation and are frameworks of 
exceptionally specific nature. However, Ogwu (2011), argued that unlike other modes of transportation such as roads, pipelines do not improve access for individuals in networks through which they pass, rather they force imperatives on connections and when found near houses, are potential risks to life. Jiaet al. (2019), in alignment, posited that transporting hazardous substances through miles-long using pipelines although has become popular across the globe in recent decades, the odds of basic mishaps because of pipeline failures have expanded. The reasons for pipelines failures are either deliberate (like vandalism or harm) or unexpected (like gadget/material disappointment/failure and corrosion) damages (Morilloet al., 2007; White et al., 2019; Ajaoet al., 2018). The average life span of oil pipeline is between 20 and 30 years. However, Adebayo (2018), noted that some pipelines in the Nigerian oil fields are over 30 years old. Omofonwan and Odia (2009), averred that aged and corroding pipelines is very common in many oil exploration fields in the Niger Delta region of Nigeria. The vast majority of the pipelines are networked through the streams, springs, marshes and farmland in the Niger Delta, a habitat that is wetland delicate, and exceptionally touchy to stretch(Ogwu, 2011; Ogon, 2006). For example, the Shell Petroleum Development Company's $95 \mathrm{~km}$ trunk line is networked from Nembe Creek field to Cawthorne Channel field running through thirty five communities and crosswise about sixty rivers and creeks of different proportions across its course (Ogwu, 2011). According to Achebe et al. (2012), a large number of the oil pipelines in the Niger Delta area were installed in the 1960s and 1970's. As at the year 2000, pipelines older than 20 years constituted $73 \%$ of all pipelines while those over 30 years old accounted for $41 \%$ of the total network length (Achebe et al., 2012). Credibility of pipelines below 20 years in use was about $46 \%$ whereas those above 30 years was about $25 \%$. Achebe et al. (2012), maintained that the old age of the pipelines in Nigeria makes them prone to failures. Failed pipelines leak petroleum into the environment resulting in contamination and pollution.

Globally, hydrocarbons pollution of different matrices of the environment has been documented. For example, Pathak et al. (2011), investigated the effect of petroleum oil on soils located in the area of Jaipur, India. The soil samples collected were analysed using the GC-MS technique in determining the load of TPH in both contaminated and noncontaminated sites. The results showed that the chemical content for Petroleum Contaminated Soil-1 (PCS-1) and Petroleum Contaminated Soil-2 (PSC-2) were $11149 \mathrm{mg} / \mathrm{kg}$ and $14244 \mathrm{mg} / \mathrm{kg}$ respectively whereas $700 \mathrm{mg} / \mathrm{kg}$ and 614 $\mathrm{mg} / \mathrm{kg}$ respectively were recorded for uncontaminated soils, indicating anthropogenic source of pollution in the area. Iturbeet al. (2004), investigated the load of hydrocarbons in soil around a refinery in Mexico, and reported that main source of contamination of soil was from pipelines, and old storage tanks in addition to the land disposal of untreated hydrocarbon sediments derived from the cleaning of storage tanks in the area. Gworeket al. (2018), assessed the ecological risk of soil contaminated by the activities of a petrochemical industry in Warsaw, Poland, using a multi-stage Triad procedure. The results showed that the permissible contamination levels of benzene, ethylbenzene and toluene (among the nine analyzed VOCs) and anthracene, benzopyrene and total PAHs (among the eleven PAHs examined) were exceeded in some of the soil plots studied, compared to the EPA and Dutch intervention standards. The authors revealed that the presence of pollutants have lowered the biodiversity indices and consequently, deteriorated the soil quality of the study area. They recommended that appropriate remediation techniques be employed to clean up the soil. In another study, Pinedoet al. (2013), analyzed the levels of TPH, PAHs and BTEX in 62 samples collected from different oil and gas facilities in Netherlands, and found out that TPH and PAH concentrations were above the Netherlands target values for contaminated sites and were mainly found in medium and heavy oil products such as diesel and heavy oil. According to them, unacceptable BTEX concentrations were obtained in soils contaminated with gasoline and kerosene. Okop and Ekpo (2012), investigated soil contamination due to crude oil spillage in Ikot Ada Udo in Akwa Ibom State, Nigeria. The results showed that total petroleum hydrocarbon levels for topsoil, subsoil and soils at greater depths ranged from $9-289 \mathrm{mg} / \mathrm{kg}$, $8-318 \mathrm{mg} / \mathrm{kg}$ and $7-163 \mathrm{mg} / \mathrm{kg}$ respectively. The smallest level of hydrocarbon was recorded in the deepest level of soil while greatest degree occurred in the middle soil level. In comparison with the reference sites, the results revealed higher load of total petroleum hydrocarbon. They concluded that it is necessary to have a complete and sustainable environmental monitoring system and remediation. For decades, it has been known that contaminated air, soil and water due to hydrocarbon and heavy metals can affect humans causing environmental health risks (Humoud, 2017; Certiniet al., 2013). A number of studies have been carried out on the human diseases caused by exposure to hydrocarbon contaminated soil, water, air and food crops. Ordinioha and Brisibe (2013); Osman (1997); Campbell et al. (1993), reported that the influence of hydrocarbon contamination on human health can affect both physical and mental health resulting in genetic disorder, heart disease, headaches, throat irritation and itchy eyes, infertility, cancer, lumbar pain, migraine, dermatitis, etc. PAHs (especially the heavy molecular weight) are of principal concern due to their intractable, staying power, bioaccumulation and potential to cause cancer (Igwoet al., 2010; Castorena-Torres et al., 2008; Xue and Warshawsky, 2005). USEPA (2002), identified a list of 16 PAHs as priority pollutants to be controlled due to the effects they might have on the human health and the environment. These include Naphthalene, Acenaphthylene, Acenaphthene, Fluorene, Phenanthene, Anthracene, Fluoranthene, Pyrene, Chrysene, Benzo(a)anthracene, Benzo(k)fluoranthene, Benzo(a)pyrene, Benzo (j) fluoranthene, Indeno (123-cd) pyrene, Dibenz (ah)anthracene, Benzo (ghi) perylene. On the other hand, BTEX are defined priority pollutants by USEPA (2002). They represent a threat to human health and ecosystems because of their toxicity (ATSDR, 2004). These are some justifications why hydrocarbons such as TPH, BTEX and PAHs should be monitored in our fragile environments.

\section{Materials and Methods}

\subsection{The Study Area}

This study was carried out in Idu (Lat $5^{\circ} 15^{\prime} 0.64^{\prime} \mathrm{N}$, Long $\left.6^{\circ} 35^{\prime} 43.68^{\prime} \mathrm{E}\right)$ communities in Ogba/Egbema/Ndoni Local Government Area of Rivers State, Nigeria. Geographically, Idu Communities are located about 60km Northwest of Port 
Harcourt, Rivers State.The communities within the study area are IduObosi-Uku and IduOsobile. The area is characterized by streams and floodplain. The vegetation type is typical of freshwater with diverse and rich floristic composition. The climate is tropical with rainy season between the Months of April and October and dry season between the Months of November and March. Temperature range in the area is between $25^{\circ} \mathrm{C}$ and $32^{\circ} \mathrm{C}$. Farming and fishing are the major occupation of the people. The major water body in the area is the Orashi River. The general language spoken in the communities is Ogba. The communities are blessed with land resources that the dwellers utilize for farming activities. The two communities play host to two international oil companies. There are farms in and around the area. The inhabitants are people of different income class. Besides oil and gas activities in the area, there are other visible businesses owned by artisans and petty traders in the two communities. The general settlement pattern is dispersed with some linear characteristics identifiable in the location of houses along access roads and internal streets. Fig. 1is the map of Nigeria showing the Local Government Area (Ogba/Egbema/Ndoni) in Rivers State where the study was carried out.

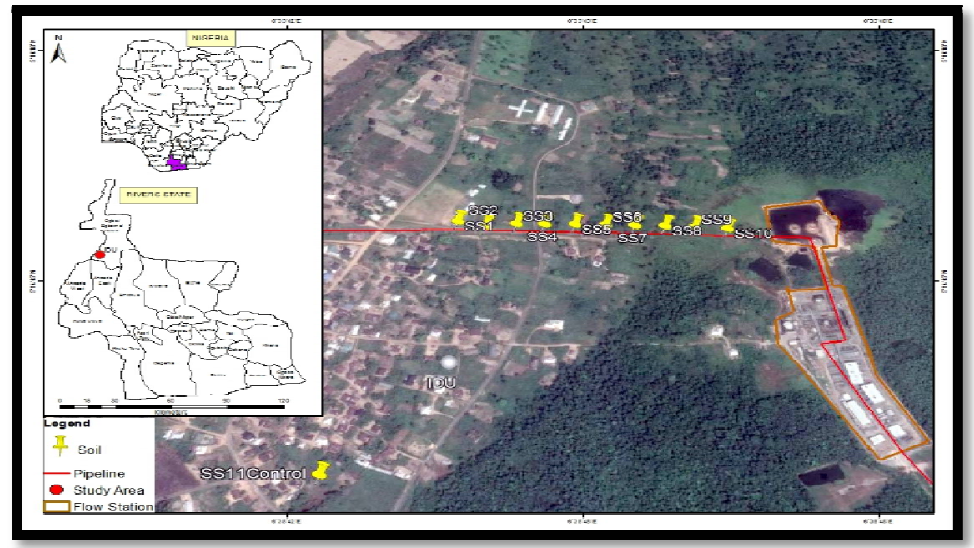

Figure 1: The Map of Nigeria Showing the Local Government Area (Ogba/Egbema/Ndoni) in Rivers State Where the Study Was Carried Out

\subsection{Collection of Soil Samples}

Soil samples were collected from ten stations quarterly for one year (twelve months). The samples were collected precisely on the $2^{\text {nd }} J a n u a r y, 2019,2^{\text {nd }}$ April, 2019, $2^{\text {nd }}$ July, 2019 and $2^{\text {nd }}$ October, 2019 respectively. Soil samples were also collected at $1.5 \mathrm{~km}$ away from the pipeline route quarterly as control. A total of eighty-eight (88) soil samples were collected across the study stations and control. Soils were collected at two depths $(0-15 \mathrm{~cm}$ and $15-30 \mathrm{~cm}$ depths $)$ at each sampling station using the soil Auger. The collection of samples was done by taking 2-3 auger borings of soil at each sampling station with a Dutch Auger and bulked together to make a composite sample. At each quarterly sampling, the samples were collected in properly labeled foil plates and taken to the laboratory for analysis. In the laboratory, the soil samples were analysed for TPH, PAHs and BTEX content.

\subsection{Chemical Analysis}

The method measures individual and total concentrations of extractable volatile, aliphatic, aromatic and petroleum hydrocarbons components in soil samples using Headspace/Purge and trap gas chromatography mass spectrometry after liquid-liquid/soxhlet extraction as well as mixed hydrocarbon solvent (n-hexane and dichloromethane). The extract was then concentrated using a rotary evaporator, clean up in a glass packed silica-gel and sodium sulphate column and then fractionated. The fractions were eluted into their individual components using n-hexane for aliphatic hydrocarbon and dichloromethane for aromatic hydrocarbons.

\subsection{Statistical Analysis}

Means, standard deviations and Analysis of Variance (ANOVA) as well as Duncan multiple range test of hydrocarbons in soil were calculated. Pollution load index (PLI) was used to assess the presence and degree of TPH, PAH and BTEX contamination of soil.

The PLI is obtained using [58] approach as follows:

$$
\mathrm{PLI}=[\mathrm{CF} 1 \times \mathrm{CF} 2 \times \mathrm{CF} 3 \times \ldots \ldots . \mathrm{C} \mathrm{n}] 1 / \mathrm{n}
$$

Equation 1;

where, $\mathrm{CF}=$ contamination factor; and $\mathrm{n}=$ specific number of contaminants studied.

\subsection{Quality Assurance and Control}

Quality assurance/quality control was an integral part of the research work. Basically, the quality assurance and control programme ensured that the integrity of the samples collected was not compromised. Specifically, we ensured that;

- Contamination of samples was avoided by use of clean sampling materials;

- The auger was cleaned after each sampling to avoid cross-site contamination

- Samples were collected in foil plates, correctly labeled and preserved;

- $\quad$ Field and equipment blanks were collected as appropriate. 


\begin{tabular}{|c|c|c|}
\hline PARAMETER & Target Values (DPR, 2018) (mg/Kg) & Intervention Values (DPR, 2018) (mg/Kg) \\
\hline TPH (mg/Kg) & 50 & 5000 \\
\hline PAH (mg/Kg) & 1 & 40 \\
\hline BTEX (mg/Kg) & - & - \\
\hline
\end{tabular}

Table 1: Environmental Guidelines and Standards for Soil for the Petroleum Industry in Nigeria (EGASPIN) (2018 Revised)

Source: [15]

\section{Results and Discussion}

\subsection{Results}

Total petroleum hydrocarbon was generally high across the study stations in all the quarters of the year (QI, Q2, Q3 and Q4) (January, April, July and October) in both surface and subsurface soils (Table 2 and Fig. 2). PAH concentrations were detected in all the study stations both in surface and subsurface soils in Q1, Q2, Q3 and Q4 (Fig. 3). BTEX concentrations recorded in surface and subsurface soils were below equipment detection limit of $0.001 \mathrm{mg} / \mathrm{kg}$ in both study and control stations across the four quarters of the year (Table 2).

\begin{tabular}{|c|c|c|c|c|c|c|c|c|c|c|c|c|}
\hline \multirow[t]{3}{*}{ Parameters } & \multicolumn{12}{|c|}{ Study Stations $(0-15 \mathrm{~cm})$} \\
\hline & \multicolumn{3}{|c|}{ 1 $^{\text {st }}$ Quarter } & \multicolumn{3}{|c|}{$2^{\text {nd }}$ Quarter } & \multicolumn{3}{|c|}{$3^{\text {rd }}$ Quarter } & \multicolumn{3}{|c|}{$4^{\text {th }}$ Quarter } \\
\hline & $\begin{array}{l}\text { 㟧 } \\
\text { 鹿 }\end{array}$ & $\begin{array}{l}+1 \\
\stackrel{\text { ॠ }}{\Sigma}\end{array}$ & 它 & $\begin{array}{l}\text { 品 } \\
\text { 鹿 }\end{array}$ & $\begin{array}{l}+1 \\
\stackrel{+}{\Xi} \\
\Sigma\end{array}$ & 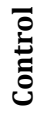 & 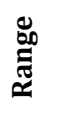 & $\begin{array}{l}+1 \\
\stackrel{\Xi}{\varpi} \\
\sum^{ \pm}\end{array}$ & 它 & 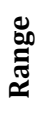 & $\begin{array}{l}+1 \\
\stackrel{+}{\Xi} \\
\sum^{ \pm}\end{array}$ & 葡 \\
\hline 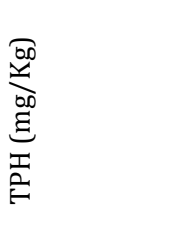 & 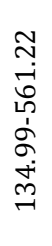 & 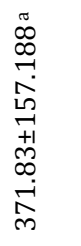 & 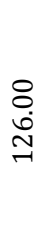 & 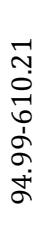 & 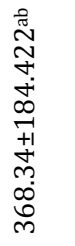 & $\begin{array}{l}\stackrel{?}{1} \\
\stackrel{0}{9}\end{array}$ & 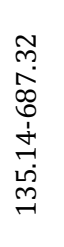 & 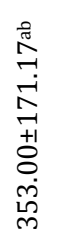 & $\begin{array}{l}\stackrel{\infty}{m} \\
\stackrel{m}{\infty} \\
\stackrel{m}{m}\end{array}$ & 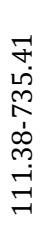 & 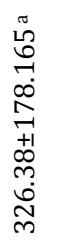 & $\begin{array}{l}\text { N్} \\
\text { ت్ } \\
\exists\end{array}$ \\
\hline 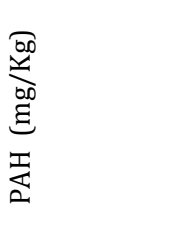 & 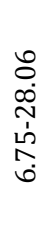 & 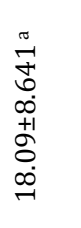 & $\stackrel{\text { }}{\circ}$ & 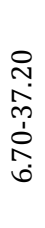 & 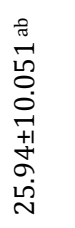 & $\begin{array}{l}\infty \\
\stackrel{\infty}{\infty} \\
\stackrel{2}{2}\end{array}$ & 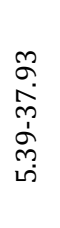 & 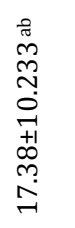 & స్హ & $\begin{array}{l}2 \\
\alpha \\
+ \\
m \\
\dot{+} \\
m \\
\infty \\
\infty\end{array}$ & 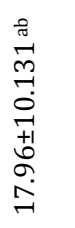 & 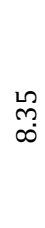 \\
\hline 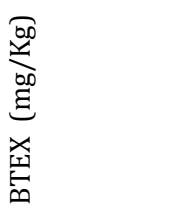 & $\begin{array}{l}\overrightarrow{0} \\
\dot{0} \\
\dot{v}\end{array}$ & 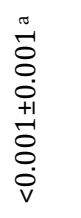 & $\begin{array}{l}\vec{\Delta} \\
\dot{0} \\
\dot{v}\end{array}$ & $\begin{array}{l}\overrightarrow{8} \\
\dot{0} \\
\dot{v}\end{array}$ & $\begin{array}{l}\tilde{a} \\
\stackrel{0}{0} \\
0 \\
+1 \\
0 \\
0 \\
\dot{0} \\
\dot{v}\end{array}$ & $\begin{array}{l}\overrightarrow{8} \\
\dot{0} \\
\dot{\mathrm{v}}\end{array}$ & $\begin{array}{l}\overrightarrow{8} \\
\dot{0} \\
\dot{v}\end{array}$ & 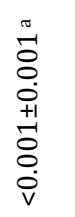 & $\begin{array}{l}\overrightarrow{8} \\
\dot{0} \\
\dot{v}\end{array}$ & $\begin{array}{l}\tilde{8} \\
\dot{0} \\
\dot{v}\end{array}$ & 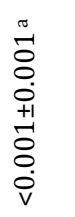 & $\begin{array}{l}\overrightarrow{8} \\
\dot{0}\end{array}$ \\
\hline \multicolumn{13}{|c|}{ STUDY STATIONS $(15-30 \mathrm{~cm})$} \\
\hline 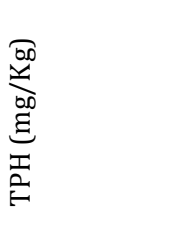 & 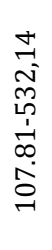 & 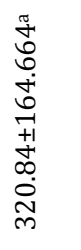 & $\begin{array}{l}\stackrel{8}{\circ} \\
\underset{\exists}{\exists}\end{array}$ & 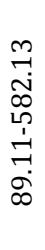 & 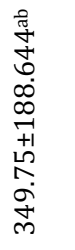 & $\begin{array}{l}\hat{N} \\
\text { g. }\end{array}$ & 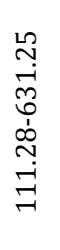 & 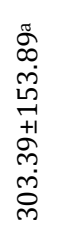 & $\begin{array}{l}\overrightarrow{7} \\
\text { a } \\
\overrightarrow{7}\end{array}$ & 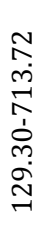 & 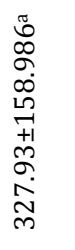 & $\begin{array}{l}\text { के } \\
\text { ळे }\end{array}$ \\
\hline 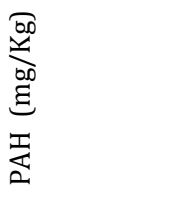 & $\begin{array}{l}\hat{\alpha} \\
\dot{\sim} \\
\dot{T} \\
\dot{d} \\
\dot{m}\end{array}$ & 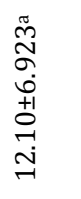 & $\begin{array}{l}\text { ö } \\
\dot{m}\end{array}$ & 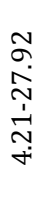 & 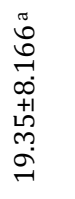 & $\begin{array}{l}m \\
\stackrel{\infty}{\infty}\end{array}$ & $\begin{array}{l}\vec{\infty} \\
\stackrel{+}{+} \\
\stackrel{\sim}{\sim} \\
\vec{\sim}\end{array}$ & 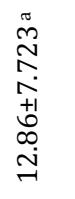 & i. & 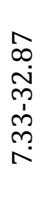 & 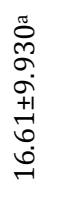 & $\begin{array}{l}\stackrel{\infty}{n} \\
\stackrel{n}{2}\end{array}$ \\
\hline 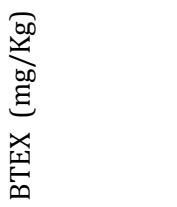 & $\begin{array}{l}\bar{\partial} \\
\dot{0} \\
\dot{v}\end{array}$ & $\begin{array}{l}\stackrel{\pi}{0} \\
0 \\
0 \\
+1 \\
\stackrel{0}{0} \\
\dot{0} \\
v\end{array}$ & $\begin{array}{l}\vec{\Delta} \\
\dot{0} \\
\dot{v}\end{array}$ & $\begin{array}{l}\overrightarrow{8} \\
\dot{0} \\
\dot{v}\end{array}$ & 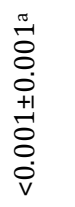 & $\begin{array}{l}\overrightarrow{8} \\
\dot{0} \\
\dot{v}\end{array}$ & $\begin{array}{l}\dot{a} \\
\dot{0} \\
\dot{v}\end{array}$ & $\begin{array}{l}\stackrel{0}{0} \\
0 \\
0 \\
+1 \\
+ \\
0 \\
\dot{0} \\
\dot{0}\end{array}$ & $\begin{array}{l}\vec{a} \\
\dot{0} \\
\dot{v}\end{array}$ & $\begin{array}{l}\vec{\Delta} \\
\dot{0} \\
\dot{v}\end{array}$ & $\begin{array}{l}\stackrel{0}{0} \\
0 \\
0 \\
+1 \\
+ \\
0 \\
\dot{0} \\
\dot{0}\end{array}$ & $\begin{array}{l}\vec{\Delta} \\
\dot{0} \\
\dot{v}\end{array}$ \\
\hline
\end{tabular}

Table 2: Summary of Hydrocarbons Characteristics of Soil in the Study Area

Mean \pm S.D across the Columns with Different Superscript Were Significantly Different At 5\% with $A>B>C$. Mean Separation Done by Duncan Multiple Range Test 


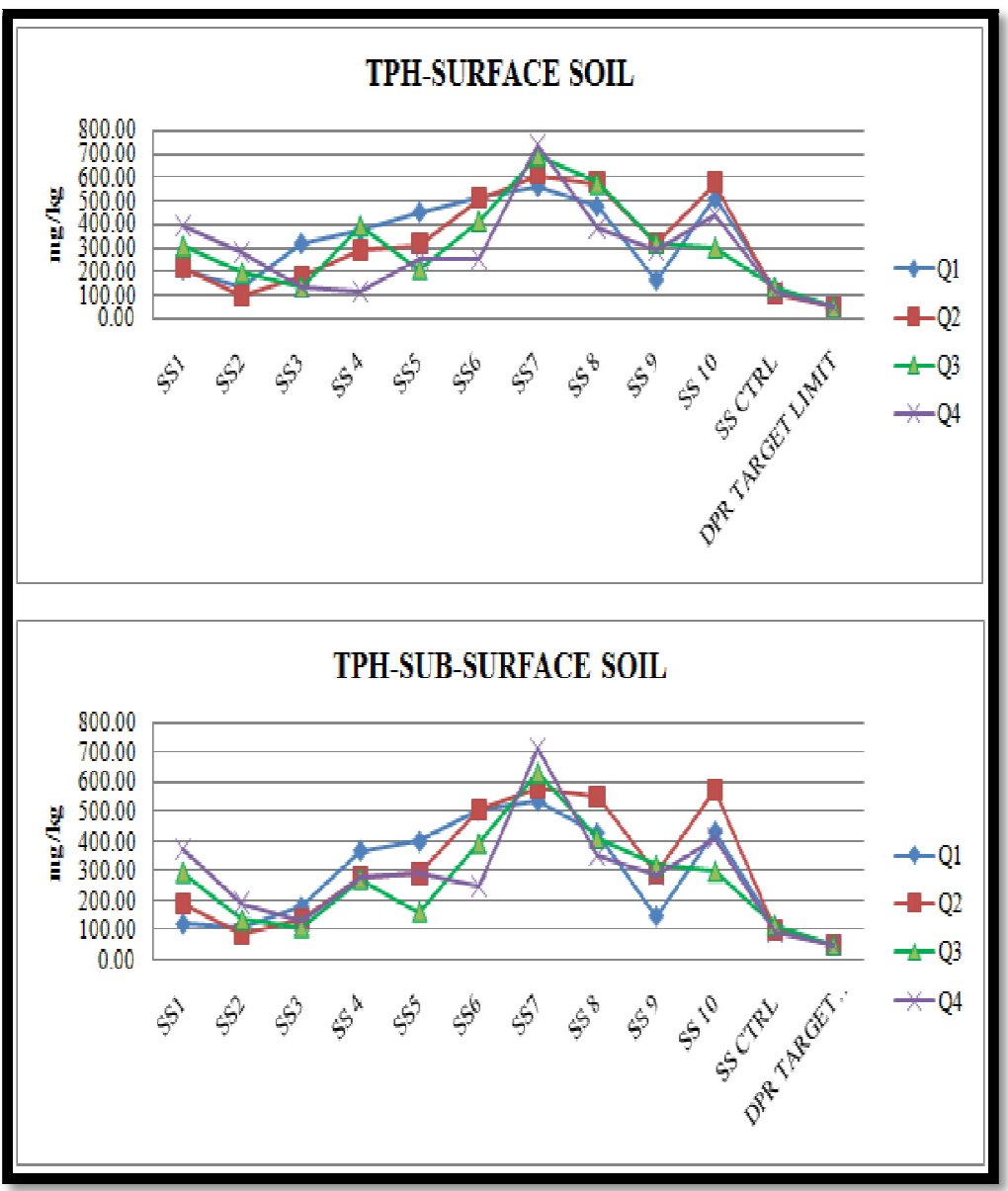

Figure 2: Total Petroleum Hydrocarbons Concentrations across Study Stations in Surface and Subsurface Soils in the Study Area in January, April, July and October, 2019

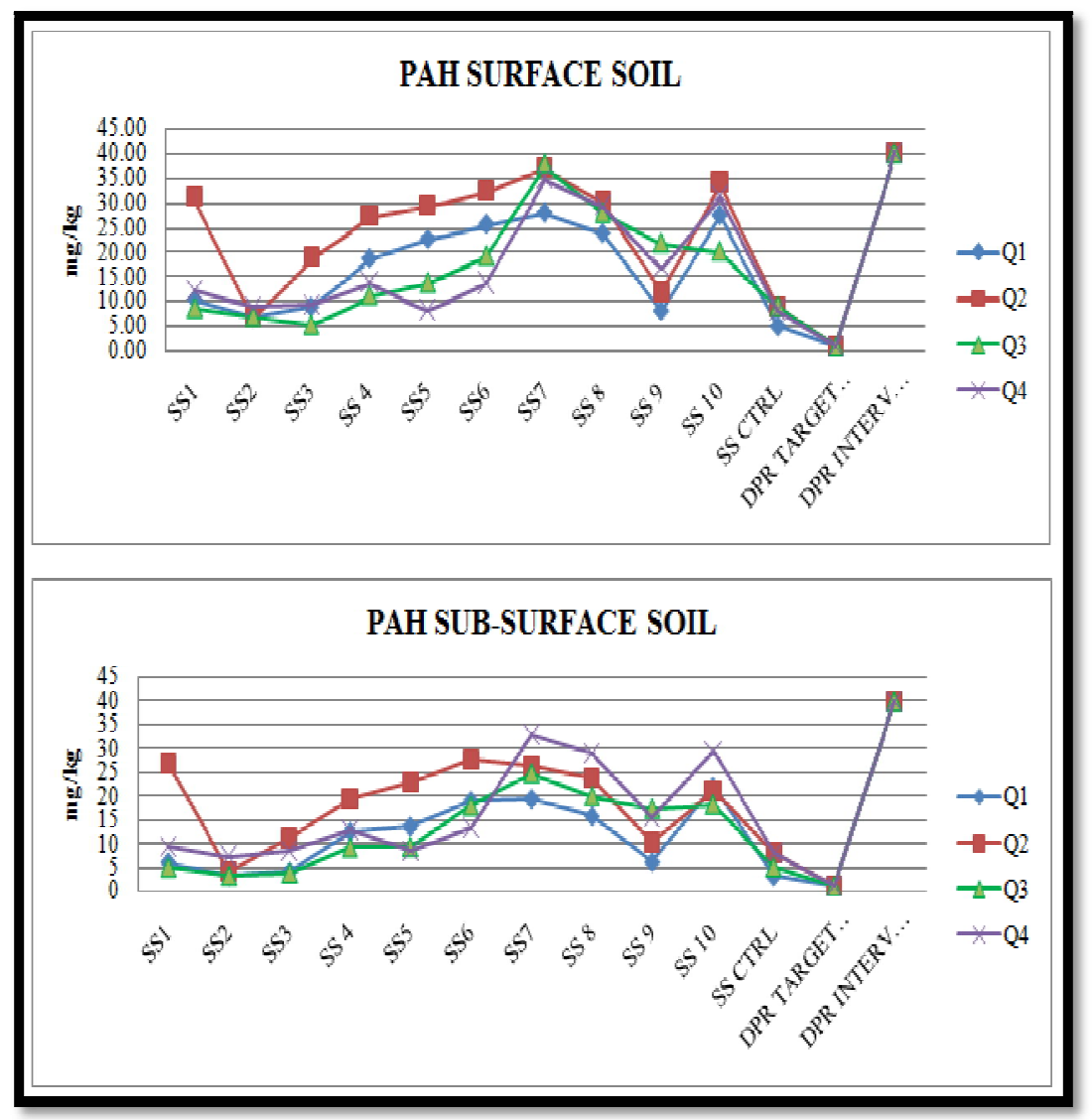

Figure 3: PAH Concentrations across Study Stations in Surface and Subsurface Soils in the Study Area in January, April, July and October, 2019 


\begin{tabular}{|c|c|c|c|c|}
\hline \multirow[t]{2}{*}{ Study Stations } & \multicolumn{4}{|c|}{ Parameters } \\
\hline & $\begin{array}{l}\text { Total Hydrocarbon Conc. } \\
\text { (TPH + PAH + BTEX) }\end{array}$ & CF & DC & PLI \\
\hline SS1 & 554.78 & 2.31 & 30.16 & 3.11 \\
\hline SS2 & 318.83 & 1.33 & & \\
\hline SS3 & 347.15 & 1.44 & & \\
\hline SS4 & 624.02 & 2.6 & & \\
\hline SS5 & 626.49 & 2.61 & & \\
\hline SS6 & 877.85 & 3.65 & & \\
\hline SS7 & 1323.71 & 5.5 & & \\
\hline SS8 & 985.62 & 4.5 & & \\
\hline SS9 & 561.49 & 2.33 & & \\
\hline SS10 & 934.46 & 3.9 & & \\
\hline SSCTR & 240.622 & 1 & & \\
\hline
\end{tabular}

Table 3: Hydrocarbons Contamination and Pollution Load Index of Soil in the Study Area

\subsection{Discussion}

The comparisons made in this study were based on concentrations of the control (reference) soils, as well as target and intervention values of the Department of Petroleum Resources (DPR) as enshrined in Environmental Guidelines and Standards for Soil for the Petroleum Industry in Nigeria (EGASPIN) (2018 Revised).

\subsubsection{Total Hydrocarbon Petroleum (TPH)}

The mean concentrations obtained were $371.83 \mathrm{mg} / \mathrm{kg}, 368.34 \mathrm{mg} / \mathrm{kg}, 353.00 \mathrm{mg} / \mathrm{kg}, 326.38 \mathrm{mg} / \mathrm{kg}$, and 320.84 $\mathrm{mg} / \mathrm{kg}, 349.75 \mathrm{mg} / \mathrm{kg}, 303.39 \mathrm{mg} / \mathrm{kg}, 327.93 \mathrm{mg} / \mathrm{kg}$ in surface and subsurface soils in Q1, Q2, Q3 and Q4 respectively (Fig. 2). TPH concentrations decreased as depth increased, which could be attributed to the physical properties (especially porosity and permeability) of soil in the study area. This finding is in agreement with similar studies conducted earlier by Sari et al. (2018) in Indonesia, Iwegbueet al. (2003) in Nigeria; O’Reilly et al. (2001), in America, who reported that soil with low or moderate permeability has low potential for hydrocarbon migration. The TPH values recorded were generally higher than $126 \mathrm{mg} / \mathrm{kg}, 107.20 \mathrm{mg} / \mathrm{kg}$, $135.38 \mathrm{mg} / \mathrm{kg}, 113.29 \mathrm{mg} / \mathrm{kg}$, and $111.00 \mathrm{mg} / \mathrm{kg}, 99.27 \mathrm{mg} / \mathrm{kg}, 118.17 \mathrm{mg} / \mathrm{kg}$, and $96.39 \mathrm{mg} / \mathrm{kg}$ obtained in surface and subsurface soils at the control points in Q1, Q2, Q3 and Q4 (January, April, July and October) respectively. This observation indicates anthropogenic source of contamination of soil with hydrocarbons in the study area

Moreover, the TPH concentrations obtained were not significantly different ( $>0.05$ ) across the four quarters of the year (January, April, July and October). However, there was significant difference $(\mathrm{p}<0.05)$ in TPH load across the sampling stations. This suggested that anthropogenic activities in the study area might have influenced the sampling stations differently. For example, TPH levels obtained were generally highest at sampling station 7 (SS 7), followed by sampling station 10 (SS 10). This observation suggests that the pipeline might be leaking at these points. The suspected pipeline leakage could be attributed to pressure on the connecting branches as these two sampling stations were close to the flow station in the area. Pipeline transportation of crude oil from pump or flow station generates pressure, and loses force over time and distance. Klass (1986), had noted earlier that pressure wave may occur in pipeline transporting product if the velocity of the flowing liquid suddenly changes.

Besides, the suspected leakage could be attributed to corrosion due to the old age of the pipeline. Previously, Omofonwan and Odia (2009), in their study noted that aged and corroding pipeline is very common in many oil exploration fields in the Niger Delta region. The average life span of oil pipeline is between 20 and 30 years. Conversely, the pipelines in the study area were installed in the 1970's, indicating that they are over 30 years old. This observation agreed with Adebayo (2018), who noted that some pipelines in the Nigerian oil fields are over 30 years old. The concentrations of TPH obtained in soil across the sampling stations including $735.41 \mathrm{mg} / \mathrm{kg}$ recorded at study station 7 , exceeded the Department of Petroleum Resources (DPR) target value of $50 \mathrm{mg} / \mathrm{kg}$ for oil spilled site in Nigeria. This is an indication that all the sites were strongly contaminated with hydrocarbons. Hydrocarbon polluted soil affects crops yield and can threaten regional food security and public health. In agreement with the finding in this study, Benson and Odinwa (2010), in their earlier research found out that cassava planted in hydrocarbon polluted soil recorded low yield while land degradation reduced productivity and contributed to low efficiency of the farmers. Similarly, Inoniet al. (2006), in their study reported that soil polluted with hydrocarbons reduced crop yield, land productivity, farm income and overall local economy. The findings in this study were comparable to the results reported by Okop and Ekpo (2012); Iwegbue and Nwajei (2008); Onianwa (1995); Adekambi (1989).However, the concentrations obtained were lower than the values reported by Iwegbueet al. (2007), in Nigeria, Iturbet al. (2004); Saariet al. (2007),in Finland. Although the TPH concentrations obtained in this study exceeded the Department of Petroleum Resources (DPR) target value of $50 \mathrm{mg} / \mathrm{kg}$ for a spilled site in Nigeria, it is far below $5000 \mathrm{mg} / \mathrm{kg}$ intervention value. 


\subsubsection{Polycyclic Aromatic Hydrocarbon (PAHs)}

The soil was generally contaminated with PAHs. Among the 16 PAH components listed as criteria pollutants that were investigated in this study, Naphthalene (Nap) had the lowest concentration across the sampling stations. The low concentrations recorded for 2 - ring PAHs could be due to their high volatility. Anthrancene (Ant), phenanthren (Phen) and fluorine (Flu) were abundant in all the sampling stations however, higher in SS1, SS2, SS3, SS4, SS5, SS6, SS8, SS9 than SS7 and SS10. Whereas among the $4-6$ ring PAHs investigated, prominent among them were benzo (a) pyrene, benzo (k) fluoranthene, benzo (b) fluoranthene, fluoranthene, pyrene, indenol [1,2,3 - cd] pyrene, benzo [ghi] perylene, dibenzo [a,h] anthrancene, chrysene and benzo (a) anthrancene. The order of dominance for 3 - ring PAHs was Ant $>$ Phen $>$ Flu $>$ acy, while for $4-6$ ring PAHs, the order was $\mathrm{B}(\mathrm{a}) \mathrm{P}>\mathrm{B}(\mathrm{k}) \mathrm{P}>\mathrm{B}(\mathrm{b}) \mathrm{F}>\mathrm{Flt}>\mathrm{Pyr}>\mathrm{IP}>\mathrm{B}(\mathrm{g}, \mathrm{h}, \mathrm{i}) \mathrm{P}>\mathrm{DB}(\mathrm{ah}) \mathrm{A}>\mathrm{Cry}>\mathrm{B}(\mathrm{a}) \mathrm{A}$. The result showed that Ant, Phen, $\mathrm{B}(\mathrm{a}) \mathrm{P}$ and $\mathrm{B}(\mathrm{k}) \mathrm{F}$ were among the predominant contributors of PAHs in the study area. This finding is in agreement with Lie et al. (2017); Ma and Zhou (2011); Lorset al. (2012), who reported in their studies that Phe and $\mathrm{BbF}$ are among the predominant PAHs in soil. The other most abundant components among the heavy molecular weight PAHs obtained were $\mathrm{B}(\mathrm{a}) \mathrm{P}, \mathrm{B}(\mathrm{k}) \mathrm{P}, \mathrm{B}(\mathrm{b}) \mathrm{F}$, Flt and B(g,h,i)P which are typical tracers for fossil fuel combustion (Lie et al. 2017). This was expected because oil and gas exploration is the predominant anthropogenic activities in the study area.

Furthermore, the trend observed in the distribution of PAHs in both surface and subsurface soils indicated a common origin suspected to be petrogenic. The total PAH mean concentrations obtained were $18.09 \mathrm{mg} / \mathrm{kg}, 25.94 \mathrm{mg} / \mathrm{kg}$, $17.38 \mathrm{mg} / \mathrm{kg}, 17.96 \mathrm{mg} / \mathrm{kg}$ in surface soil, and $12.10 \mathrm{mg} / \mathrm{kg}, 19.35 \mathrm{mg} / \mathrm{kg}, 12.86 \mathrm{mg} / \mathrm{kg}, 16.61 \mathrm{mg} / \mathrm{kg}$ in subsurface soil in Q1, Q2, Q3, and Q4 respectively. The result obtained showed that the concentrations of total PAHs decreased as depth increased. This observation can be attributed to the low mobility of PAHs in soil (Li et al., 2010; Wang et al., 2001). In a previous study conducted by Cornelissen et al. (2005), they observed that PAHs accumulated in the topsoil and had very low vertical migration rate because of its strong sorption towards soil organic matter (SOM) and any other absorbing materials. The total PAHs load obtained at the control point were $5.05 \mathrm{mg} / \mathrm{kg}, 9.08 \mathrm{mg} / \mathrm{kg}, 9.12 \mathrm{mg} / \mathrm{kg}, 8.35 \mathrm{mg} / \mathrm{kg}$ in surface soil, and $3.02 \mathrm{mg} / \mathrm{kg}, 8.13 \mathrm{mg} / \mathrm{kg}, 5.01 \mathrm{mg} / \mathrm{kg}, 7.98 \mathrm{mg} / \mathrm{kg}$ in subsurface soil in Q1, Q2, Q3, and Q4. Although these values were lower in comparison to the values obtained across the sampling stations, it obviously showed that PAHs were common pollutants in the study area. The higher concentrations obtained at the sampling stations indicated anthropogenic influence attributable to the oil and gas activities in the area. The values obtained were comparable to mean values of $16.19 \mathrm{mg} / \mathrm{kg}, 11.93 \mathrm{mg} / \mathrm{kg}, 18.00 \mathrm{mg} / \mathrm{kg}, 18.4 \mathrm{mg} / \mathrm{kg}$ reported by Kim et al. (2018); Morilloet al. (2007); Van et al. (2014); Bradley et al. (1994), in UK and USA respectively however, higher than $0.03979 \mathrm{mg} / \mathrm{kg}, 0.035 \mathrm{mg} / \mathrm{kg}$ reported by Emoyanet al. (2011); Echemet al (2019), and lower than $3830 \mathrm{mg} / \mathrm{kg}, 896.784 \mathrm{mg} / \mathrm{kg}$, and $86.3 \mathrm{mg} / \mathrm{kg}$ reported in Niger Delta by Nwaichiet al. (2014); Osu and Okoro (2012); and in India by Sarmaet al (2016) respectively. Although the TPAH concentrations obtained in this study exceeded the Department of Petroleum Resources (DPR) target value of $1 \mathrm{mg} / \mathrm{kg}$ for a spilled site in Nigeria, it is below the $40 \mathrm{mg} / \mathrm{kg}$ intervention value.

\subsubsection{Benzene, Toluene, Ethylbenzene and Xylene (BTEX)}

BTEX concentrations recorded in surface and subsurface soils were below equipment detection limit of 0.001 $\mathrm{mg} / \mathrm{kg}$ in both study and control stations across the four quarters of the year (January, April, July and October). This finding can be attributed to their volatility, which is in agreement with the previous studies conducted by Echemet al. (2019), in Gokana; Duan and Li (2017), in China. Benzene, toluene, ethyl benzene and xylene are classified as priority pollutants regulated by many environmental organizations around the world including USEPA and DPR.Prolonged exposure to high concentration of BTEX is toxic and can have mild to severe effects on health including damages to kidneys, nervous system, liver, eyes, and exacerbation of respiratory conditions (PTL, 2016).

\subsection{Degree of Contamination (DCI) and Pollution Load Index of Soil}

Hydrocarbons contamination of soil across the sampling stations was highest at SS 7 with contamination factor of 5.50. The order of contamination was SS $7>$ SS $8>$ SS $10>$ SS $6>$ SS $5>$ SS $4>$ SS $9>$ SS $1>$ SS $3>$ SS 2 . The degree of hydrocarbons contamination (30.16) and pollution load (3.11) indices recorded indicated that the soils were highly contaminated nevertheless, with moderate pollution load. The hydrocarbons pollution load showed a localized pattern, evidenced by higher concentrations of TPH and PAH obtained at sampling station 7 than other stations.

\section{Summary and Conclusion}

This study has established that leaking underground petroleum facilities including pipelines has the potential of exposing man to high load of hydrocarbons via food chain. The concentrations of TPH and PAH obtained in soil exceeded their respective target values of $50 \mathrm{mg} / \mathrm{kg}$ and $1 \mathrm{mg} / \mathrm{kg}$ stipulated by the Department of Petroleum Resource (DPR) in oil spilled soil but below their respective intervention values of $5000 \mathrm{mg} / \mathrm{kg}$ and $40 \mathrm{mg} / \mathrm{kg}$. This implies that the study sites may not require remediation. Nevertheless, a program such as pipeline integrity test should be implemented by the oil and gas operators in the area. This will identify leakages and if timely repaired, the soil could recover through natural attenuation. Periodic monitoring of pipelines and other underground petroleum facilities such as flow and service stations in Niger Delta region of Nigeria is strongly recommended for healthy environment.

\section{References}

i. Achebe, C.H., Nneke, U.C. and Anisiji, O.E. (2012). Analysis of Oil Pipeline Failures in the Oil and Gas Industries in the Niger Delta Area of Nigeria. Proceedings of the International Multi-Conference of Engineers and Computer Scientists. Vol. 2, Pp 6 
ii. Adebayo M. (2018). Oil spills and their impact on the Niger Delta. B.Sc. Thesis, Helsinki Metropolia University of Applied Sciences. Pp 55

iii. Adekambi, E.O. (1989). Petroleum hydrocarbon pollution of Nigerian waters and sediments around Lagos and Niger Delta areas of Nigeria. Ph.D. Thesis, University of Ibadan, Ibadan. Pp. 241

iv. Ajao, L.A.; Adedokun, E.A.; Nwishieyi, C.P.; Adegboye, M.A.; Agajo, J. and Kolo, J.G. (2018). An Anti-Theft Oil Pipeline Vandalism Detection: Embedded System Development. Int. J. Eng. Sci. Appl., 2: 55-64

v. Arosanyin, G.T (2005) Pipeline Transportation of Petroleum Products in Nigeria: Threats, Challenges and Prospects. Central Bank of Nigeria Economic and Financial Review. Vol. 43 No. 2:1-36.

vi. ATSDR (2004). Agency for Toxic Substances and Disease Registry (ATSDR). Public Health Statement, Zinc. 7440-66-6.

vii. Benson, D. N and Odinwa, A. B. (2010). Impact of crude oil exploration and production on the yield and Income of Cassava (Manihotspp) in Khana Local Government Area, Rivers State, Nigeria. Africa J. Agric. Res. Dev. 3(3): $59-64$

viii. Bhattacharyya, S. and Andon, B. (2010). Analysis of oil export dependency of MENA countries: Drivers, trends and prospects. Energy Policy, 38: 1098-1107.

ix. Bradley, L. J. N., Magee, B. H. and Allen, S. L. (1994). Background levels of polycyclic aromatic hydrocarbons $(\mathrm{PAH})$ and selected metals in New England urban soils. Journal of Soil Contamination 34: 1-13

x. Campbell D., Cox, D., Crum, J., Foster, K., Chrístie, P.and Brewster, D. (1993). Initial effects of the grounding of the tanker Braer on health in Shetland. British Medical Journal (BMJ), 307(6914): 1251-1255

xi. Castorena-Torres, F., M. Bermudez de Leon, B. Cisneros, O. Zapata-Perez, J.E. Salinas and A. Albores (2008). Changes in gene expression induced by polycyclic aromatic hydrocarbons in the human cell lines HepG2 and A549. Toxicol. In vitro, 22: 411-421

xii. CEIC (2019). Global Economic Data, Indicators, Charts and Forecast 2019. Accessed 24th September, 2019

xiii. Certini, G., Scalenghe, R., and Woods, W. (2013). The impact of warfare on the soil environment. Earth-Science Reviews, 127, 1-15.

xiv. Cornelissen, G., Gustafsson, O., Bucheli, T.D., Jonker, M., Koelmans, A.A. and Van Noort, P. (2005). Extensive sorption of organic compounds to black carbon, coal, and kerogen in sediments, and soils: mechanisms and consequences for distribution, bioaccumulation and biodegradation. Environ. Sci. Technol., 39: 6881-6895

xv. DPR (2018). Department of Petroleum Resources (DPR). 'Environmental Guidelines and Standards for the Petroleum Industry in Nigeria' (EGASPIN, 2018 revised). DPR: Lagos, Nigeria

xvi. Duan, X. and Li, Y. (2017). Sources and fates of BTEX in the general environment and its distribution in coastal cities of China. J Environ Sci Public Health, 1 (2): 86-106

xvii. Echem O. G., Kalagbor I.A. and Lucky G.B. (2019). Determination of PAHs and BTEX in soil and crops (Cocoyam and Cassava) of crude oil impacted community, Mogho, Gokana, Nigeria. International Journal of Sciences, 5(8):234 - 230

xviii. Emoyan, O O.; Agbaire, P 0.; Otobrise C. and Akporhonor, E E. (2011).Distribution pattern of polyaromatic hydrocarbons (PAHs) in soils in the vicinity of fuel stations in Abraka, Nigeria. J. Appl. Sci. Environ. Manage. 15 (3): $513-516$

xix. Europe's Energy Portal (2018). Available at https://www.energy.eu/. Retrieved on 3rd October, 2019

xx. Gworek B., Baczewska-Dąbrowska, A.H., Kalinowski, R., GoÂrska, E.B., Rekosz-Burlaga, H., Gozdowski, D., Olejniczak, I., IGraniewska, M. and Dmuchowski W. (2018). Ecological risk assessment for land contaminated by petrochemical industry. ERA for land contaminated by organic compounds. Available at https://doi.org/10.1371/journal.pone.0204852. Pp 15

xxi. Humoud, M.Z.A. (2017). A Geotechnical, Geochemical and Human Health Risk Assessment of a Dry Oil Lake Site in Kuwait. Ph.D. Thesis, University of Portsmouth, UK. Pp 742

xxii. Igwo-Ezikpe M. N, Gbenle O. G, Ilori M.O, Okpuzor J. and Osuntoki A. A. (2010). High molecular weight polycyclic aromatic hydrocarbons biodegradation by bacteria isolated from contaminated soil in Nigeria. Res. J. Environ. Sci., 4: 127-137.

xxiii. Inoni, O. E., Omotor, D. G. and Adun, F. N. (2006). Effect of Oil Spillage on Crop Yield and Farm Income in Delta State, Nigeria. J. Central Eur. Agric. 7(1):41 - 48

xxiv. Iseru E., Fagbemi E., Awolola K. and Akpovwovwo T. (2014). Mitigating external corrosion failures in buried petroleum pipelines in Nigeria: A review. International Journal of Ecological Science and Environmental Engineering, 1(2): 67-72

xxv. Iturbe, R., Flores, R.M. Flores, C.R. and Torres, L.G. (2004). TPH contaminated Mexican soil. Health risk assessment and the first year of changed. Environmental Monitoring and Assessment, 91(1-3): 237-255

xxvi. Iwegbue, C.M.A. and Nwaje, G.E. (2008). Characteristic levels of total petroleum hydrocarbon in soil profile of automobile mechanic waste dumps. International Journal of Soil Science, 3 (1): 48-51.

xxvii. Iwegbue, C.MA.,Nwajei, G.E. and Arimoro, F.O. (2007). Characteristic level of total petroleum hydrocarbon in soil, sediment and surface water of an oil impacted area in the Niger Delta. Pakistanjournal of Scientific andIndustrial Research, (50)4: 247-250

xxviii. Iwegbue, C.M.A., Williams, E.S., Nwajei, G.E. (2003). Characteristic levels of total petroleum hydrocarbon in soil profiles of automobile mechanics waste dumps. Inter. J. Soil. Sci., 3(1): 48-51

xxix. Jia, Z.; Wang, Z.; Sun, W.; Li, Z. (2019). Pipeline leakage localization based on distributed FBG hoop strain measurements and support vector machine. Optik, 176: 1-13 
xxx. Kim, A.W., Vane, C.H., Moss-Hayes1, V.L., Beriro, D.J., Nathanail, C.P., Fordyce, F.M. and Everett, P.A. (2018). Polycyclic aromatic hydrocarbons (PAHs) and polychlorinated biphenyls (PCBs) in urban soils of Glasgow, UK. Earth and Environmental Science Transactions of the Royal Society of Edinburgh, 1-17

xxxi. Klass, A.B. (1986). Pipeline Transportation of Oil: Production and Transport of Oil and Gas: Second edition. Pp. 278

xxxii. Li, H. L., Chen, J. J., Wu, W. and Piao, X. S. (2010). Distribution of polycyclic aromatic hydrocarbons in different size fractions of soil from a coke oven plant and its relationship to organic carbon content. Journal of Hazardous Materials, 176: 729-734

xxxiii. $\quad$ Lie, X., Bai, Z., Yu, Q., Cao, Y. and Zhou, W. (2017). Polycyclic aromatic hydrocarbons in the soil profiles (0-100 $\mathrm{cm}$ ) from the industrial district of a large open-pit coal mine, China. RSC Advances, 7: 28029-28037

xxxiv. Lors, D. Damidot, J. Ponge and Perie, F. (2012). Comparison of a bioremediation process of PAHs in a PAHcontaminated soil at field and laboratory scales.Environ. Pollut., 165: 11-17

xxxv. Ma, J. and Y. Zhou, Y.Z. (2011). Soil pollution by polycyclic aromatic hydrocarbons: a comparison of two Chinese cities. J. Environ. Sci., 23: 1518-1523

xxxvi. Morillo, E., Romero, A. S., Maqueda, C., Madrid, L., Ajmone- Marsan, F., Grcman, H., Davidson, C. M., Hursthouse, A. S. and Villaverde, J. (2007). Soil pollution by PAHs in urban soils: a comparison of three European cities. Journal of Environmental Monitoring, 9: 1001-08

xxxvii. Mutiu A. A., Wai-Keung, F. and Aditya, K. (2019). Recent advances in pipelines monitoring and oil leakage detection technologies: Principles and approaches. Sensors, 19: 122 - 153

xxxviii. Nnah, W.W. and Owei, O.b. (2005). Land Use Management Imperative for Oil and Gas Pipeline Network in Nigeria, Abuja. Pp 17

xxxix. Nwaichi, E.O., Wegwu, M.O. and Nwosu, U.I. (2014). Distribution of selected carcinogenic hydrocarbon and heavy metals in an oil-polluted agriculture zone. Environ Monit Assess. 186:8697-8706

xl. Ogon, P.R. (2006). Oil and Gas: Crises and Controversies 1961 - 2000. Brentwood: Multi-science Publishing Co. Ltd

xli. Ogwu, F.A. (2011). Challenges of oil and gas pipeline network and the role of physical planners in Nigeria. Forum Journal, 10: 41-51.

xlii. Okop, J.I. and Ekpo, S.C. (2012). Determination of total hydrocarbon content in soil after petroleum spillage. Proceedings of the World Congress on Engineering. Vol. III.

xliii. Omofonwan, S.I. and Odia, L. O. (2009). Oil exploitation and conflict in the Niger-Delta Region of Nigeria. Journal of Human Ecology, 26(1): 25-30

xliv. Onianwa, P.C. (1995). Petroleum hydrocarbon pollution of urban top soil in Ibadan city, Nigeria. Environment International, 21(3): 341-343

xlv. Ordinioha, B. And Brisibe, S. (2013). The human health implications of crude oil spills in the Niger delta, Nigeria: An interpretation of published studies. Nigeria Medical Journal, 54(1):10-6

xlvi. O'Reilly, K.T., Magaw R.I., Rixey, W.G. (2001). Predicting the Effect of Hydrocarbon and Hydrocarbon-Impacted Soil and Groundwater. API's Soil and Groundwater Technical Task Force. API Publication No. 14

xlvii. Osman, Y. (1997). Environmental surveys conducted in the Gulf region following the gulf war to identify possible neurobehavioral consequences. Environmental Research, 73(1-3): 207-210

xlviii. Osu, C.I. and Okoro, I. A. (2012). Distribution of organic compounds (PAHs and BTEX) and heavy metals (Pb, Zn, Fe, Cd) in an oil impacted soils, Rivers State Nigeria. CheSci Rev Lett, 1(1): 133-139

xlix. Parry, I.W.H. and Darmstadter, J. (2003). The Cost of U.S. Oil Dependency. Discussion Paper. Pp 40

l. Pathak, H., Bhatnagar, K., and Jaroli, D. (2011). Physico-chemical properties of petroleum polluted soil collected from transport nagar (Jaipur). Indian Journal of Fundamental and Applied Life Sciences, 1(3), 84-89

li. Pinedo J., Ibáñez R., Lijzen J.P.A and, Irabien A. (2013). Assessment of soil pollution based on total petroleum hydrocarbons and individual oil substances. Journal of Environmental Management, 72 - 79

lii. PTL (2016). Phoslab Testing Laboratories. BTEX: Risks and Control Measures. Available online at https://www.phoslab.com/btex-risks-and-control-measures

liii. Saari, E., Peramaki, P. and Jalonen, J. (2007). Effect of sample matrix on the determination of total petroleum hydrocarbons (TPH) in soil by gas chromatography-lame ionization detection. Microchemical Journal, 87(2): 113-118

liv. Sari, G.L.,Trihadiningrum, Y. and Ni'matuzahroh (2018). Petroleum hydrocarbon pollution in soil and surface water by public oil fields in Wonocolo Sub-district, Indonesia. Journal of Ecological Engineering, 19(2): 84-193

lv. Sarma, H., Islam, N.F., Borgohain, P., Sarma, A. and Prasad, M.N.V. (2016). Localization of polycyclic aromatic hydrocarbons and heavy metals in surface soil of Asia's oldest oil and gas drilling site in Assam, northeast India: Implications for the bio-economy. Emerging Contaminants (2): 119 - 127

lvi. Speight.J. (1999). The Chemistry and Technology of Petroleum. Marcel Dekker. Pp 177

lvii. $\quad$ SRWE (2018). Statistical Review of World Energy. Retrieved 21 June 2018. Pp 56

lviii. Tomlinson, D.L., Wilson, J.G Harris, C.R. and Jeffrey, D.W. (1980). Problems in the assessment of heavy metal levels in estuaries and the formation of a pollution index. Helgol. Meeresunters, 33: 566 - 575

lix. USEIA (2019). United States Information Administration. International Energy Outlook 2019. Released date: September 24, 2019. Pp 85

lx. USEPA (2002). U.S. Environmental Protection Agency, 2002 Edition of the drinking water standards and health advisories: Washington, D.C., U.S. Environmental Protection Agency, Office of Water, EPA/822/R-02/038. 
lxi. Vane, C. H., Kim, A. W., Beriro, D. J., Cave, M. R., Knights, K., Moss-Hayes, V. and Nathanail, P. C. (2014). Polycyclic aromatic hydrocarbons (PAH) and polychlorinated biphenyls (PCB) in urban soils of Greater London, UK. Applied Geochemistry 51: 303-14.

lxii. Wang, X. C., Zhang, Y. X. and Chen, R. F. (2001). Distribution and partitioning of polycyclic aromatic hydrocarbons (PAHs) in different size fractions in sediments from Boston harbor, United States. Marine Pollution Bulletin, 42: 1139-1149

lxiii. White, B.; Kreuz, T. and Simons, S. (2019). Midstream. In Compression Machinery for Oil and Gas; Klaus, B., Rainer, K., Eds.; Gulf Professional Publishing: Houston, TX, USA, 2019; pp. 387-400.

lxiv. Xue, W. and Warshawsky, D. (2005). Metabolic activation of polycyclic and heterocyclic aromatic hydrocarbons and DNA damage: A review. Toxicol. Applied Pharmacol., 206: 73-93. 